\title{
Political Interconnection in the Operation of Digital Terrestrial Free-to-Air Television Broadcasting
}

\author{
Rahayu•
}

\begin{abstract}
Agent(s) role in the implementation of policies is frequently considered as the determining factor for the success of policy implementation. This is reflected quite clearly in the "principleagent" theory that describes how self-interested agent influences the implementation process. However, is self-interested agent still relevant in explaining Indonesia's broadcasting policy implementation? What if policy implementation involved many actors with their respective personal interests? How will agents position themselves amidst numerous personal interestbearing actors? By using the political economy approach, this research aims to reveal the role of agents in the constellation of actors' relation to Indonesia's broadcasting policy implementation. The operation of digital terrestrial free-to-air television broadcasting case is used to provide a reflection of agents' position and political behavior in responding to the interest among actors. This research was conducted using the qualitative approach by implementing the data collection technique through in-depth interviews and document analysis. The research result shows that broadcasting policy implementation is not merely influenced by a self-interested agent but is also influenced by political interconnection and multiple-principles' political-economic interest.
\end{abstract}

\section{Keywords:}

policy implementation; broadcasting; political economy; agent; multiple-principles.

\section{Introduction}

The 1998 political reform has provided an opportunity for reformists defenders of democracy to establish democratic institutions for supporting change into a better-improved course of order (Crouch, 2010). In the context of television broadcasting in Indonesia, this reform has driven changes in the television broadcasting system, from one that was authoritarian and centralistic into one that is democratic and decentralized (Pandjaitan \& Siregar, 2003; Siregar, 2008). One of the manifestations of this change was the advent of Broadcasting Law number 32 of 2002, which is often considered to be a milestone of political change in Indonesian broadcasting.

In the Broadcasting Law, the path to realizing democratic and decentralized broadcasting has been made quite clear. This course is explicitly stipulated in both the consideration section and main body of the Broadcasting Law. In the considerations, the objective of broadcasting operation is explicitly formulated, of which among others are: to guarantee the citizens' right of convey their opinions and obtain information, to achieve public welfare in utilizing radio frequency spectrum as a limited natural resource, to maintain diversity of the Indonesian people, and to implement regional autonomy. The

\footnotetext{
- Department of Communication Sciences, Faculty of Social and Political Sciences, Universitas Gadjah Mada

Email: rahayu@ugm.ac.id
} 
main body of the Broadcasting Law has also regulated and acknowledged the presence of four types of broadcasting organization (public, private, community, and subscription broadcasting organizations) to guarantee diversity of contents and voices. The law contains regulation that prevents business monopoly and provides specifications on the distribution of authorities among the broadcasting regulatory institutions.

Despite the stipulations having been explicitly written in the Broadcasting Law, a number of people, particularly broadcasting activists and civil society organizations, concerned with broadcasting issues in Indonesia (such as: Armando et al., 2011; Nugroho et al., 2012; Judhariksawan, 2013; Rianto et al., 2014; Heychael et al., 2014). They said, the implementation of the said law is not in accordance with the objective of the law. A case that is quite controversial relates to the Regulation of the Minister of Communication and Information Technology on the operation of digital terrestrial free-to-air television broadcasting. Several objections in relation to the omission of the Indonesian Broadcasting Commission's (Komisi Penyiaran Indonesia-KPI) authority to manage digital broadcasting, the change of broadcasting system that caused the switch off from analog to digital, the advent of new broadcasting institution called multiplex broadcasting service institution that has the authority to lease frequencies, and biased industrial management over big television. ${ }^{2}$

This study was conducted to understand what is truly the interest of the state, of which in this case is the Ministry of Communication and Information Technology (Kementerian Komunikasi dan Informatika-Kemenkominfo), in issuing such policy? If the Minister of Communication and Information Technology (Menkominfo) is the implementer of the law,

\footnotetext{
${ }^{2}$ Summarized from the claim description delivered by ATVJI and ATVLI in claim document number 38P/ HUM/2012 and number 40.P/HUM/2012.
}

why was a policy that contradicts the mandate of the law made? Did agents have a self-interest in that incidence and if so, what is their selfinterest? What is the response of the legislative as the branch responsible for monitoring the executive, or the response of the Indonesia Broadcasting Commission in this case as the public's representation? Even further, the researcher would like to explore the issue of political interconnectivity between actors and their interests in the operation of digital television broadcasting.

Based on literature review results, it seems that studies on policy implementation have yet to touch on the roles and interests among actors. Initial studies on implementation were inclined to observe policy implementation from the administrative procedure aspect (Pressman \& Widavsky, 1973). Scholars in this stage (such as van Meter \& Horn, 1975, p. 462-476; Sabatier \& Mazmanian, 1980) view the issue of implementation being caused by problems such as uncertainty of policy aspect, bureaucratic issues, low level of implementer reliability, and influence of societal surroundings. Implementers tend to be viewed as neutral and act based on rationality (Schofield, 2004; Matland, 1995).

In the following development, studies were found to be dominated by the assumption that implementers have control over implementation as they are regarded to be closer to and understand the actual issues occurring on the field. Those studies focused on target groups and service delivery. Those studies began with the target's need for a policy (not with the policy), then the investigation moves upward toward the capacity of the implementer-how the implementer influenced behaviors and allocated resources to achieve policy objectives - , and ended with policy evaluation (Elmore, 1979). Through such procedure, the issue of implementation is seen as an impact of the agent's capability to understand the target group and develop 
appropriate service delivery strategy. The similarity of this research with previous studies is that the role and position of agent in policy implementation are considered as being neutral (Fischer, et al., 2015).

Sabatier and Mazmanian (1980) have presented quite a comprehensive outlook in viewing the factors that influence policy implementation. They distinguish the factors influential to implementation into two: policy (content) and non-policy (context). The policy factor includes policy clarity, availability/ absence of-of study results serving as policy basis, financial resource sufficiency, integration of executing organization, recruitment of executing official, and formal access of executor to other organizations. The non-policy factors include social economic and technological conditions, media attention to policy issues, public support, attitude and resource of the main target group, commitment and authority support, and capacity of executing official.

Based on prior research, a study on actors remains unnoticed. Although a few studies on the subject exist, scholars tend to place them in a bureaucratic-procedural, hierarchic structure. This is, perhaps, brought about by the scholars' point of view that is inclined to see implementation solely as a process of pure administration (Matland, 1995, p. 147-8).

Positioning actors in such hierarchical structure would distance them from the reality that actors, including implementing agents, can or may act on the basis of personal or group interest and that the implementation process is satiated with political interests (Grindle \& Thomas, 1989). This structure is also lacking in its observation of the reality that certain types of relationships among actors may also contribute to deviations in policy implementation. Herman and Chomsky (2002), for instance, show how political-economic interests, as witnessed in the compromise between capital owners or capitalists and regulators, led policy implementation to no longer become neutral and in the public interest, but is biased toward capitalistic interests instead. Due to such perspective, knowledge about how the interests of implementing agents, actors, and relations among actors actually influence policy implementation has not been much revealed.

The main thesis of this research is developed from the basic assumption of the political economy theory, namely how political interconnection and political-economic interests among actors influence the proses of policy implementation in post-reform television broadcasting and the process subsequently deviated from the objective of the law to realize a democratic and decentralized broadcasting politics in Indonesia.

Before discussing the political economy theory, we should revisit the elaboration concerning the principle-agent theory and its explanation on how self-interested agent influence policy implementation. This discussion is provided so that later in the analysis section a comparison can be made whether the issue of policy implementation is determined more by a self-interested agent(s) or rather by the influence of principle(s) interest instead.

The principle-agent theory introduced by Michael C. Jensen and William H. Meckling (1976), explains that agent has a vital role in influencing policy. This theory places its concern on the relations that emerge when an individual or a group of individuals (principle) employs one or more people (agent) for the purpose of delegating responsibility. Hereby, the principle entrusts the control of the system in the hands of the agent and the agent with their afforded authority executes their duties. However, there is no guarantee that the agent will obey the instruction of the principle as the agent have the interest to maximize their own acquisition of profit. The basic premise of this theory is that all individuals are motivated solely by their own self-interest. Weber (1978) correlated the self-interested agent with 
economic interest. Nevertheless, Goode (1997, p. 39-40) argues that self-interest also relates to the interest for power. This interest is linked to efforts in garnering the support of interest groups, obtaining support for campaign funding, or other supports/facilities.

In connection with the implementation of broadcasting policy, the relationship between the principle and the agent may be different to the domain of accountancy which mostly manages the private domain as this theory was initially developed from. In the domain of broadcasting policy, there are quite a number of parties with their own interests because the issue at hand deals with the public domain, wherein the wider public has the right to the available resources and the state has the obligation of managing it fairly in order to realize social welfare. There is, thus, the possibility that there's not just one principle in this case, but many layers of them. They all expect the agent to take the best measures in implementing the policy according to their expectations. Here, the researcher realized the limitation of the principle-agent theory in explaining the issue of policy implementation.

A number of literature on political media economy (such as Underhill, 2000; Herman \& Chomsky, 2002; Golding \& Murdock, 1997; Graham, 2007; Mosco, 2009) show states under the control of capitalist groups. It is described in the literature that capitalist groups, namely capital owners and/or media entrepreneurs, are the most active and influential interest group when compared to other interest groups in influencing government elites. This very group also consistently acquires benefit from the government through the media policy that has been issued. This relation shows the presence of political connection among those actors wherein political; economic interest operates behind the issued policy.

Based on Mosco's (2009) view, the capitalist group actively strives to influence government policy through lobbying and furnishing rewards to secure their interests. This capitalist group is dependent on the government as it is the institution that determines prevailing policies. This group also dominates relations due to the power of capital they own. The relationship between politics (power) and economy (capital) here is clearly a manifestation of a certain group's (the capitalists) struggle. Various evidence showing power or dominance of the capitalist group in broadcasting cases can be examined through a number of studies, such as in Napoli (2001b) and Stavitsky (1994).

An actual illustration of interests and political interconnection has been presented by Ambardi (2008) through the concept of the cartelized political party. Such cartelization was established in Indonesia following the general election process wherein competition among political parties no longer became obvious. Ambardi mentions that party competition ends after the election and it is subsequently followed by the making of a cartel. The origin of the cartelized party system is the collective dependency of various parties to engage in rent-seeking to fulfill their financial needs. This, in turn, creates a situation in which the party's economic and political fate is linked as a collective. Their survival as individuals is determined by their capability to maintain the cartel's existence. The common interest of the political parties to secure their financial needs compels them to place their representatives in the executive ministerial cabinet and in the leadership structure at the commission level of the Parliament (Ambardi, 2008).

Based on the explanation above, the government as a representative of political party cartel may view their collaboration with the capitalist group as beneficial. In addition, the government may also see opportunities forrent-seeking in the world of broadcasting. 


\section{Methods}

This research employed the qualitative approach by applying the methods of in-depth interview and document analysis to gather data. In-depth interviews were conducted to obtain responses of actors connected to the operation of digital television broadcasting. The interviews are expected to show political relations and political-economic interests among the actors. The interviews were conducted for eight months (March until October 2017) by involving 48 respondents from Jakarta, Yogyakarta, Makassar and Bali. The informants consisted of the government (Kemenkominfo), KPI/KPID, private television broadcasting operators, regional government, National/Regional Legislative (DPR/DPRD), broadcasting activists and observers, and former officials who had held positions in the government, legislative body, or broadcasting regulatory body. Document analysis was conducted for the purpose of acquiring supporting data that relates to the political actions carried out by the actors, their interests, and how the relations among actors were established.

The data analysis of the study results was carried out in several stages. Firstly, the researcher classified the results of document analysis based on certain themes relating to the study matter. Secondly, the researcher transcribed all data obtained from the interviews into a verbatim format and applied coding. The coding result was subsequently classified into themes as well. The data obtained from document analysis was also classified. Thirdly, once all the data have been collected according to the themes, the researcher applied matching patterns to find similarities or differences in them. Fourthly, based on the above stages, the researcher made a conclusion in order to answer the research question.

\section{Result}

\section{Actors with Interest}

The researcher have identified at least six actors (group of actors) that had an interest in television broadcasting in Indonesia and they showed that they actively responded to policies, particularly those relating to the Minister of Communication and Information Technology Regulation (Permenkominfo) on the operation of digital terrestrial television broadcasting (namely Permenkominfo 22 of 2011 and Permenkominfo 32 of 2013). The six actors were the Indonesian Broadcasting Commission (KPI-Pusat (national) and KPIDaerah (regional)), Jakarta private television broadcasting institutions with national broadcast coverage (which will subsequently be called Jakarta-TV) and their corresponding associations (such as, the Indonesian Private Television Association/ATVSI), local private television broadcasting institutions (which will subsequently be called Local-TV) and their corresponding associations (such as ATVLI and ATVJI), civil society organizations and their affiliates (such as KIDP, SIKA, KNRP), the People's Representative Council (DPR), and the government. ${ }^{3}$

The Indonesian Broadcasting Commission in the Broadcasting Law (Article 7 verse 2) is stated to be "an independent state institution that regulates broadcasting related matters." However, the authority of this institution had long been curtailed due to a judicial review in $2003^{4}$ that rendered the KPI to merely retain the

\footnotetext{
${ }^{3}$ Aside from the six actors, there were also others such as the Public Broadcasting Institutions (TVRI and RRI), community broadcasting institutions, etc. that will voice their concerns in relation to the broadcasting policy. However, these institutions are not included in the discussion of this article as the focus of study is aimed at the issue of commercial broadcasting operation.

${ }^{4}$ The trimming began with a judicial review case challenging the Broadcasting Law that was filed by the Indonesian Television Journalists Association (IJTI), the Indonesian National Private Radio Broadcasting Association (PRSSNI), the Indonesian Association of Advertising Agencies (PPPI), the Indonesian Television
} 
authority of regulating contents. Although its authority had been reduced, interview results with a number of KPI commissioners show that the institution remains motivated and interested in being involved in regulating Indonesian broadcasting. KPI is also expectant of obtaining funding allocation from the National Budget (APBN) to support its work programs and to make it become more independent. ${ }^{5}$

Jakarta-TV ${ }^{6}$ and their accommodating institution, such as the ATVSI, had an interest in defending their business position and gaining profit from the broadcasting business that they had established and develop. ${ }^{7}$ This institution expected the government through the regulations they make to provide legal certainty and guarantee concerning the continuity of their business. Additionally, these institutions also intend to develop their businesses, be it those related to the world of broadcasting or those that aren't (Rianto et al., 2014; Lim, 2011). All this time, big televisions that are gathered in ATVs have more than $100 \%$ control of the national private television shares. Given this position, they reap a substantial profit of trillions of rupiah per annum. ${ }^{8}$

Broadcasting Association (ATVSI), Indonesian Dubbing Association (PERSUSI), and the Indonesian Television Community (KOMTEVE). These organizations among others stated their objection to KPI's authority as it is regarded to have the potential of eliminating freedom of speech, freedom of expression, and freedom of broadcasting institutions. Although the Constitutional Court (MK) defended KPI's position, it has fundamentally reduced KPI's authority as a regulator.

${ }^{5} \mathrm{KPI}$ currently has funding allocation as well as human resource from Kemenkominfo.

${ }^{6}$ The television stations meant here are RCTI, Global TV, MNC TV (included in MNC Group), SCTV, Indosiar (EMTEC Group), ANTV, TVOne (Bakrie \& Brothers), Trans TV, Trans 7 (Trans Corpora), and Metro TV (Media Group).

${ }^{7}$ Interview with Gilang Iskandar (Corporate Secretary of SCTV and ATVSI manager), in Jakarta, May 16, 2017.

${ }^{8}$ As an illustration, the advertisement income in 2015 for RCTI reached Rp 9.9 trillion, SCTV Rp 8.8 trillion, Indosiar Rp 7 trillion, ANTV Rp 6.6 trillion, Global TV Rp 5.4 trillion, Trans7 Rp 5.1 trillion, Trans TV Rp 4.525 trillion, TV One Rp 4.5 trillion, and Metro TV Rp 2.9
Local-TV and their accommodating institutions, such as ATVLI and ATVJI, had the interest to develop their broadcast in the region and expected the government to be committed to developing a healthy broadcasting industry. All this time, Local-TV is of the view that they are a victim of government injustice, as in the case of channel allocation in the region'. Local television operators think there are many channels provided for Jakarta-TV rather than Local-TV. They stated their disappointment as the practice of network broadcasting system did not involve them. ${ }^{10}$ Additionally, they are dissatisfied with the government's stance of allowing deviant practices carried out by members of Jakarta-TV networks in operating local television to continue because some television stations do not have and do not broadcast local programs; if they do broadcast them, they will broadcast them during "graveyard slots" (with low amount of viewers) since prime time, and other slots have been taken up by programs relayed from Jakarta. ${ }^{11}$

Activists and civil society organizations that were also quite active in responding to broadcasting policies are $\mathrm{KIDP}^{12}$, $\mathrm{SIKA}^{13}$, and

\footnotetext{
trillion. This data was quoted from "Rajai Iklan Indonesia, Tiga Stasiun TV Milik Hary Tanoe Raup Rp 23,2Triliun". Retrieved July 8, 2017 from http://bisniskeuangan. kompas.com/read/2015/12/10/160000126/Rajai.Iklan. Indonesia.Tiga.Stasiun.TV.Milik.Hary.Tanoe.Raup. Rp.23.2.Triliun

${ }^{9}$ Researcher's interviews with Local TV operators in 2017.

${ }^{10}$ Interview with Muannas (Celebes TV), in Makassar, March 24, 2017.

${ }^{11}$ Researcher's interviews with Local TV operators in 2017.

${ }^{12} \mathrm{KIDP}$ is a civil society alliance advocating for more democratic Indonesian broadcasting regulators and regulation. The members of KIDP comprises of: AJI Jakarta, AJI Indonesia, Alwari (Indonesian Alliance of Radio Journalists), ICJR (Institute for Criminal Justice Reform), Indonesian Community Radio Network (JRKI), LBH Pers, Development and Press Research Institute (LSPP), Media Link, Media Regulators and Regulation Monitor (PR2Media), Remotivi, 28 Foundation, Ladang Media Foundation, Tifa Foundation.

${ }^{13}$ Members from ICJR, LBH Pers, Elsam, AJI.
} 
KNRP. ${ }^{14}$ This organization, or association to be exact, is a civil society alliance with the interest of advocating for a democratic digital broadcasting system. They actively conduct studies, state their position, draft policy briefs, compose press releases, hold press conferences, write opinions on the media, hold dialogs with DPR, and compose a revision draft of the Broadcasting Law.

Although DPR wields the authority of drafting legislation and monitoring government administration, this state institution tends to be passive in responding to the implementation of the Broadcasting Law. A number of activists representing civil society organizations revealed that position statements, policy briefs, and discussion proceedings from hearings at the council were mostly not followed up by DPR. Additionally, the stance and interest of DPR members may drastically differ from one period to the next. Ade Armando's experience in applying for the KPI member selection shows that there is a difference between the 2004-2007 period and the 2007-2010 period (Armando et al., 2011). He considered the strong stance of DPR to have vanished, this is observed from the acceptance of several names of KPI candidates recommended by ATVSI, although the candidate application process had already been closed. Armando also received criticism from Council members for criticizing a number of regulations made by the government, while in fact the exact same regulation was once requested by the previous period DPR to be postponed. The DPR's accommodative stance toward the government seems to be reinforced in the 2007-2010 period.

The government may be considered to play a central role in the implementation of broadcasting policy. This institution has taken over some of the strategic roles of television

${ }^{14} \mathrm{KNRP}$ has more than 160 members consisting of scholars and practitioners along with 20 civil society organizations that are concerned with broadcasting that is democratic, fair, and inclined to public interest. broadcasting regulation upon the judicial review ruling that provided the authority to decree governmental regulations, which functions to provide a more operational elaboration on the implementation of the Broadcasting Law. KPI, which in the initial composition of the law was expected to function as an independent regulatory body, due to political movements attempting to restrict its role, had been merely afforded the authority to regulating contents. In a number of issues dealing with permits, KPI assumes no more than a supplementary role to the government. The government's interest in broadcasting seems to be connected to the efforts of reinstating the supremacy of broadcasting regulator in the hands of the government. ${ }^{15}$

\section{Relations among Actors}

Actors with quite varied interests show relations that were far from being harmonious and were marked by a number of conflicts that involved the court. In the case of Permenkominfo (Communication and Information Technology Ministerial Regulation) on the operation of digital television broadcasting, I have categorized the groups into proponents (pros) and opponents (cons). The proponents of the Permenkominfo, among others, were KPI, Jakarta-TV (including ATVSI), and DPR. The opponents, among others, were Local-TV (including associations of ATVLI and ATVJI) and civil society organizations.

The proponents were basically of the view that the ministerial regulation (permen) provides a solution to the limitation of channels, it provides greater opportunity for the public to establish television stations, it advances the broadcasting industry, and provides better program services to the public.

\footnotetext{
${ }^{15}$ It is evident in Permenkominfo No. 22 Year 2011 on the operation of digital terrestrial free to air television. In articles 10, 13, 19, 23 and 25 that regulate digital broadcasting, including permit, is carried out by the minister. Not a single provision stated the role of KPI in it.
} 
KPI supports the Permenkominfo since they consider it important under the current conditions to provide support so that KPI has a role in the digitalization team ${ }^{16}$. This stance seems to have made KPI keep silent about the permen. By holding this position, it means that KPI is no longer much concerned with the public's rejection of the regulation. This position confirms my view that KPI is no longer committed as a "manifestation of public participation that functions to accommodate aspirations and represent public interest concerning broadcasting issues," as stipulated in Article 8 (verse 1) of the Broadcasting Law. While this institution was quite critical to a number of governmental regulations deemed biased to the industry in its initial establishment, in the subsequent periods this institution tended to be passive and compromised with policies issued by the government.

Jakarta-TV and ATVSI supported the ministerial regulation based on a number of reasons: changes in broadcasting technology are inevitable, the opportunity for improving broadcasting service quality, and also broadcasting business progress. Their support to the Permenkominfo had already been predicted because since digital broadcast had been initiated by the government in 2007, this institution had participated as a part of the Indonesian Digital Television Consortium (KTDI). This institution had also participated in the digital broadcast trial that was carried out in 2008. There was never any significant conflict between Jakarta-TV (and ATVSI) and the government concerning the issued broadcasting policies. This is because the government policies on broadcasting had

\footnotetext{
${ }^{16}$ Presented during a Focused Discussion on the Problems of Digital Television Broadcast in Indonesia, held by the Independent Journalists Alliance (AJI) and Tifa Foundation in Jakarta, Wednesday, February 26, 2014. Source: "Soal Digitalisasi Televisi, KPI Seharusnya Dilibatkan", Retrieved from http://www. antaranews.com/berita/421097/soal-digitalisasi-televisikpi-seharusnya-dilibatkan, July 12, 2017.
}

always been inclined to the interests of those television stations. ${ }^{17}$

In this case, DPR regarded the digitalization of television broadcasting as an important program to implement in line with current technological development. However, DPR, or Commission I to be precise, agreed that the digitalization process must have a legal umbrella in the form of legislation. Commission I DPR had, thus, made an initiative to revise the Broadcasting Law to include the broadcasting digitalization process in it. According to the Chairperson of Commission I DPR RI, Mahfudz, this digital permen is risky because if something were to happen, the minister would be held accountable, because the legal umbrella is a ministerial regulation. ${ }^{18}$

Meanwhile, the opponents are basically of the view that the broadcasting operation policy does not have a legal basis, the substance of the regulation contradicts the Broadcasting Law, the policy neglects the capacity of Local$\mathrm{TV}$, and there is bias to the more stable JakartaTV.

Local-TV and their associations (ATVLI and ATVJI) rejected the Permenkominfo because they sense injustice and discrimination in the policy. Through ATVLI and ATVJI they emphasized that they are not against digital broadcasting but rather the regulation of it. ATVLI objected to a number of things,

\footnotetext{
${ }^{17}$ Governmental Regulation (PP) No. 50 year 2005 on the Broadcasting Operation of Private Broadcasting Institutions, the government had also provided special treatment to these institutions at least in two things, namely: regulation on share ownership (stipulated in article 32 verse (3) of PP. No. 50 year 2002) and regulation on coverage of broadcast area in the operation of network broadcasting (as stipulated on article 36, point f PP No. 50 year 2002).

${ }^{18}$ Presented during a Focused Discussion on the Problems of Digital Television Broadcast in Indonesia, held by the Independent Journalists Alliance (AJI) and Tifa Foundation in Jakarta, Wednesday, February 26, 2014. Source: "Soal Digitalisasi Televisi, KPI Seharusnya Dilibatkan", Retrieved July 12, 2017 http://www. antaranews.com/berita/421097/soal-digitalisasi-televisikpi-seharusnya-dilibatkan
} 
among them were: KPI was not involved in digital broadcasting operation, the presence of multiplexing agents and the selection criteria which favors strong investors with broadcasting license, the obligation of collaborating with multiplexing agents in order to broadcast, the position of broadcasting institutions restricted to mere content providers, and so on. Since the government and KPI did not listen to their complaints, some of the parties, among them the Indonesian Local Television Association (ATVLI) and the Indonesian Network Television Association (ATVJI) has brought the digitalization case to court. They demand the annulment of a number of ministerial decrees and regulations relating to digitalization.

Civil society organizations with their affiliates rejected the Permenkominfo with a number of reasons, namely: it has no legal umbrella, it substantively contradicts the Broadcasting Law, the policy is considered to perpetuate ownership practices in the broadcasting industry, ${ }^{19}$ and it also threatens the existence of Local-TV. KIDP, for instance, stated that Menkominfo had discriminated certain parties in the process of broadcasting digitalization. ${ }^{20}$

\section{Political Actions of Agents}

In an interview with Henry Subiyakto, a researcher and expert staffer of the Ministry of Communication and Information Technology, he stated that the drafting of the permenkominfo employed three legal bases, namely the Broadcasting Law (in the elucidation section), PP No. 11 of 2005, and PP No. 50 of 2005. Did the three legal bases truly serve as a reference

\footnotetext{
${ }^{19}$ This explanation is quoted from a press release published by KIDP on July 19, 2012 entitled "KIDP Himbau Menkominfo Menunda Seleksi Multipleksing."

${ }^{20}$ Ahmad Budiman (2012). Menyoal kebijakan Digitalisasi Penyiaran. Info singkat Vol. V, No. 20/II/P3DI/ Oktober/2012. Retrieved August 23, 2017 from http:// berkas.dpr.go.id/puslit/files/info_singkat/Info\%20 Singkat-V-20-I-P3DI-Oktober-2013-20.pdf.
}

in the operation of digital broadcasting? Based on Law No. 12 of 2011 on Establishment of Laws and Regulations (article 8 verse 2), it is stipulated that laws and regulations (including ministerial regulations) are acknowledged and have binding legal authority by fulfilling two requirements: first, mandated by a higher tier of laws and regulations, and second, made based on authority.

Based on the article by article search of the Broadcasting Law, 10 provisions were found to give a mandate to the government in making regulations. ${ }^{21}$ Among the ten provisions, not a single one mentioned anything about digital broadcasting. The same results were acquired when a number of governmental regulations relating to the broadcasting operation were searched ${ }^{22}$ in which there was not a single article that explicitly directs the minister to make a ministerial regulation on the operation of digital broadcasting. This means that the first requirement for the Permenkominfo to be acknowledged has not been met.

As mentioned above, the presence of $\mathrm{KPI}$ as a regulator is basically unwanted by the principles because of its possibility of disrupting their interests. However, it is impossible to truly eliminate it since the principles would be confronted with the public and civil society organizations that would not let KPI be

\footnotetext{
${ }^{21}$ Article 14 verse (10) on Public Broadcasting Institutions; article 18 verse (3) on organization of quantity and coverage of local, regional, and national broadcasting areas, for broadcasting services; article 18 verse (4) on the restriction of ownership and control and restriction of cross ownership; article 29 verse (2) on licensing procedures and requirements; and so forth. .

${ }^{22}$ PP No. 11 of 2005 on Public Broadcasting Institutions, PP No. 12 of 2005 on RRI Public Broadcasting Institution, PP No. 13 of 2005 on TVRI Public Broadcasting Institution, PP No. 49 of 2005 on Foreign Broadcasting Institutions, PP No. 50 of 2005 on Broadcasting Operation of Private Broadcasting Institutions, PP No. 51 of 2005 on Broadcasting Operation of Community Broadcasting Insitution, PP No. 52 of 2005 on Broadcasting Operation of Subscription Broadcasting Institutions, PP No. 7 of 2009 on Types and Tariffs for Non-Tax State Revenue Items that apply at the Department of Communication and Information Technology.
} 
removed. The Minister had very proficiently articulated the principles' desire by reinforcing his authority. The actions taken by the Minister is apparent through his Permenkominfo No. 22 of 2011 and Permenkominfo No. 32 of 2013. In both regulations, the Minister serves as a single ruler in providing operational licenses for broadcast program operators and multiplexing operators.

To increase spectrum usage efficiency, Kemenkominfo issued Permenkominfo No. 5 of 2012 on Digital Terrestrial Free-to-Air Television Broadcasting Standards which determined the use of DVB-T2 technology as the broadcasting operation technology in Indonesia. ${ }^{23}$ With this technology, one channel of multiplexing (mux) will be able to channel as many as 12 channels for television broadcasting. Kemenkominfo also established the amount of multiplexing (mux) channels that will be open for every service area to be 6 . Five mux to be allocated for private broadcasting operation ${ }^{24}$ and one mux for the community and public broadcasting operation. ${ }^{25}$ Based on the regulation, it is predicted that there will be approximately 4,572 channels that may potentially be used for private television broadcasting operation.

\footnotetext{
${ }^{23}$ This Permen replaced Permen No. 7 of 2007 on Digital Terrestrial Broadcasting Standards for Fixed Reception Television in Indonesia which had established DVB-T (Digital Video Broadcasting-Terrestrial) as the broadcasting operational technology in Indonesia.

${ }^{24}$ It is stated in Permenkominfo No. 17 of 2012 on the Implementation of establishing multiplexing broadcasting operation and also Permenkominfo No. 6 of 2013 on the Amendment to the ministerial regulation No. 17 of 2012 on the Implementation of establishing multiplexing broadcasting operation.

${ }^{25}$ It is stated in Permenkominfo No. 22 of 2011 (article 11) "the Minister establishes TVRI Public Broadcasting Institution as an LPPPM that applies nationally without having to undergo a selection process to use 1 (one) channel of radio frequency in every service area." And Permenkominfo No. 32 of 2013 (article 14) "the Minister establishes LPP TVRI to operate Multiplexing Broadcasting through a Terrestrial System that applies nationally by using one channel of radio frequency in every service area."
}

In the operation of digital broadcasting, the Minister even initiated the multiplexing operating organization. This institution was designed to later manage the digital broadcasting infrastructure so that program operating institutions can broadcast the contents they produce. In determining the institution, the Minister issued Permenkominfo No. 32 of 2013 and Permenkominfo No. 6 of $2013 .{ }^{26}$ In the ministerial regulation it is stated that the institutions allowed to operate multiplexing, among others are: LPS (other than LPP-TVRI) that already has operating broadcasting license, has sufficient existing infrastructure and human resource, and has the capacity to pay bond money both bid bondand performance bond of which amount may reach up to hundreds of million rupiah.

With such huge sum of bond money, very few local television stations will be able to afford it. In some of the local television stations that the researcher visited, such as Celebes TV (Makassar), Fajar TV (Makassar), Jogja TV, RBTV, and AdiTV (these three are based in Yogyakarta), the operators were not approving of the bond money sum required. The tender system established by the government was also considered to have ignored the capacity of local television stations.

It is evident here that the government had purposely created a barrier to entry in the broadcasting industry. Based on the selection criteria, the Ministry of Communication and Information Technology had succeeded in selecting and determining thirty-three (33) multiplexing operating institutions. It was proven that most of these institutions were big television broadcasting institutions and/or their affiliates that had always been dominating television broadcasting in Indonesia, namely: RCTI, SCTV, Indosiar, ANTV, TV One, Trans

\footnotetext{
${ }^{26}$ Ministerial regulation on the Amendment to the Ministerial Regulation No. 17 year 2012 on the Implementation of establishing multiplexing broadcasting operation.
} 
TV, TV7 and Metro TV.

Aside from fulfilling the interest of Jakarta-TV, the Minister also very adeptly responded to the interest of political parties in terms of their intention to own television stations. How several television stations were exploited by the owners for political campaign purposes in the 2014 General Election seem to have instigated other political parties that did not own one to do so. In the Broadcasting Law, political parties are not allowed to establish or own television stations because only four broadcasting institutions are regarded as valid, namely: subscription, community, private, and public broadcasting institutions. Community broadcasting institution here is emphasized to be independent and founded by the nonpartisan community, and the presence of the institution is not for propaganda interest of a certain group. Additionally, the limitation of the analog channel makes it impossible for them to establish a television station. However, with the operation of digital broadcasting, in which there are much more digital channels available, it enables them to establish one. This limitation had "momentarily" driven political parties, like PKS, to broadcast via YouTube. ${ }^{27}$.The magnitude of political party interest became obvious with the emergence of the Broadcasting Law draft composed by DPR (version February 6 , 2017) which mentions a clause on special broadcasting by allowing political parties to operate broadcasting stations.

Political party interest also relates to political communication. Politicians often contact television station operators to obtain talking space through their media. Some would request the television stations to cover their party events, invite the party figures as speakers, and even contact the media to broadcast private events, such as birthdays

\footnotetext{
${ }^{27}$ Interview with the Head of PR DPP-PKS (at the time), Dedi Supriadi, in Jakarta, July 25, 2017.
}

and the like. ${ }^{28}$

For the government's own interest, the Minister attempted to boost Non-Tax State Revenue (PNBP). The Minister set targets of PNBP receipt and proudly announced them to the public when it had exceeded the target. In terms of broadcasting, PNBP came from radio frequency usage fee. However, I examined that the target of PNBP was not only directed at the broadcasting industry but from the telecommunication industry as well. Syaifudin (Sub-Section Head of Broadcasting at the Ministry of Communication and Information Technology ${ }^{29}$ in an interview with the researcher stated that a much more significant sum is acquired from the frequency rental income for telecommunication. In brief before the press, Tifatul Sembiring, who was the Minister of Communication and Information Technology at the time, even said that PNBP from the telecommunication sector is the second highest following the revenue acquired by the Ministry of Energy and Mineral Resources. Most of the PNBP receipts were from the Directorate General of Information and Postal Equipment and Resources, that is from frequency rentals for telecommunication industry purposes. ${ }^{30}$

\section{Discussion}

This study has identified several actors with interest in the implementation of television broadcasting policy in Indonesia. The presence of these actors could not be so easily placed as principles or agent(s) due to their layered

\footnotetext{
${ }^{28}$ Interview with Satria Narada/Bali TV (in Denpasar, July 12, 2017) and Kadek/SCTV Bali (in Denpasar, July $17,2017)$

${ }^{29}$ Interview conducted in Jakarta, May 4, 2017.

${ }^{30}$ Source from Press Release No. 2/PIH/Kominfo/2013. "Tingkat capaian dan prestasi Kementerian Kominfo tahun 2012" https://ppidkemkominfo.files.wordpress. com/2013/01/siaran-pers-awal-tahun-20131.pdf and news “PNBP Kominfo capai Rp 11,5 Triliun”. Retrieved August 22, 2017 from https://kominfo.go.id/content/ detail/1512/pnbp-kominfo-capai-rp115-triliun/0/berita
} 
roles and positions. Beginning with the principle-agent theory, the principle is the party employing the agent for the purpose of delegating responsibility. This means there is a formal structural line of command that connects the principle to the agent. Hence, neither of the actors explained above can be considered as a principle(s) nor agent(s). The relation showing principle-agent connection is observed between DPR-minister/government. However, if we were to dig deeper by considering ministerial appointment by the president, and DPR (nomination of legislative members) from political parties, then we can see that there is a tiered principle-agent relation, that is political party-DPR-president (and vice president)minister. Since KPI is basically mandated by the Broadcasting Law to manage to broadcast along with the government, then KPI can also be considered as an agent. An illustration of the multi principles and agent may be as follows:

\section{Figure 1.}

Principle-agent Connection

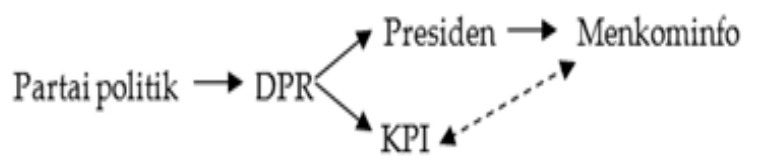

Source: research result

This tiered position and relation do not seem to correspond with the control or monitoring function that should be carried out. As mentioned earlier, Permenkominfo on the operation of digital television broadcasting ended with an annulment by the MA. The digitalization process that had been undergoing due process is currently at a standstill. Amidst the controversy, there are nearly no voices heard be it from the president, DPR, and political parties, as well as KPI, commenting on the minister's initiative in creating and maintaining the regulation. Only DPR stated their support while reminding the need to wait for a legal umbrella; the rest is silent. This silence is a political stance. This stance may be understood as a position of support; comments may perhaps be unnecessary since the agent has been entrusted to carry out its duties with the given authority. This position may also be understood as an effort to 'develop an image' due to the arguably significant public resistance to the policy. A wrong stance may have a negative impact on one's image and would subsequently affect their votes. DPR invited the minister several times to discuss the operation of digital television broadcast, but the sessions were more about listening to elaborations from the minister rather than reminding and instructing ministerial policy to be in line with the mandate of the Broadcasting Law. ${ }^{31}$

How is it possible that there is a uniformed stance in responding to the digital policy given the tiered position and relation? This study shows that there are political interconnection and common interest among the principles as well as the agent. As illustrated by Ambardi (2008) in "cartelized political party," after the general election, competition among political parties ends. The ensuing process is the formation of cartels wherein political parties that once competed engage in collaboration and mutually work together to maintain their survival. The common interest of political parties compels them to place their representatives in the cabinet and in leadership boards at the commission level in the Parliament (Ambardi, 2008). That is the reason why a different position in an institution does not necessarily mean a different person since the individuals positioned there are their people as well. Hence, it is very commonplace that their voices be in tune when facing particular

\footnotetext{
${ }^{31}$ Results of examining transcripts of the Public Hearing (RDPU) with Commission I DPR RI, April 6, 2015. "Digitalisasi Penyiaran Televisi - Rapat Komisi 1 dengan Asosiasi Televisi Siaran Digital Indonesia". Retrieved July 19, 2017 from http://www.tvdigitaljogja.tv/2015/06/ digitalisasi-penyiaran-televisi-rapat.html
} 
issues. In the case of the ministerial regulation on digitalization (No. 22 year 2011 and 32 year 2013) for example, we can see the political interconnection between the President (Susilo Bambang Yudhoyono, from the Democratic Party, PKS one of its main supporters), the Minister (Tifatul Sembiring, from the Democratic Party), Chair of Commission I (Mahfid Siddiq from the Democratic Party), and the Democratic Party (as the winner of the 2009 legislative election by acquiring 150 seats $(26,4 \%)$ ).

How is this interconnection linked to the capitalist group, such as Jakarta-TV? It is known that media conglomerates have close relations with politicians and some politicians are media owners as well. These media owners openly show their political affiliations (Lim, 2011) and some are even positioned as party leader. As elaborated by Merlyna Lim (2011), Surya Paloh, who is the chair at Media Group is also a leader in the National Democratic (Nasdem) Party. Paloh was also the chair of the Golkar Party's board of advisors. Aburizal Bakrie who is head of the Bakrie \& Brothers group was the chairman of the Golkar Party. Chairul Tanjung who owns Trans TV and Trans 7 has close ties to former president Susilo Bambang Yudhoyono. Hary Tanoesudibjo who is a leader in MNC Group was a prominent figure in Hanura and is currently the chairman of the Perindo Party with close ties to several figures in a number of influential parties. Under such conditions, the interest of political parties and the interest of the media is intertwined and is difficult to untangle.

Among the principles and agent above, the actor bearing the potential to become an opposition is KPI. Yet, KPI is no stranger to the DPR and to the capitalist group. The interview with a KPI commissioner candidate who is a former DPR member shows that the KPI commissioner selection process is far from being objective. ${ }^{32}$ DPR through the

\footnotetext{
${ }^{32}$ Interview with Kristiawan/applicant to KPI-Central (in
}

factions displays interest in making deals with the commissioner candidates who intend to garner support. This does not only happen at the national level but at the regional as well in the KPID selection by the DPRD. ${ }^{33}$ The accommodating candidate will gain support from the faction/party throughout the selection process. Such is also the case with the industry, in which they conduct a "silent operation" by lobbying council members and factions to recommend the commissioner candidates they consider supportive of their interests. ${ }^{34}$

In order to operate digital television broadcasting, the Minister had taken a risk by acting outside the legal jurisdiction. Such audacity surely had strong reasoning behind it. One of the possibilities is that the Minister was an 'ally' and executor of a mandate from political elites who held control of the state. This fact concurrently indicates that the agent of the act undertake more significantly influenced by the common interest of the principles rather than the self-interest of the agent. The agent in this case truly functioned as a representative or delegation of the principles in accomplishing their interest. What the agent had done was none other than what the principles desired.

\section{Conclusion}

In exploring the issue of policy implementation, it is imperative to understand political interconnection and common interest among actors. This study shows that self-interested agent is not the main actor who determines the orientation of policy implementation. Multiple-principles, namely political parties, DPR, President, who are the

Jakarta, May 16, 2017) and Paulus Widiyanto/former DPR Commission I member (in Jakarta, May 18, 2017).

${ }^{33}$ Interview with Muliartha/former KPID-Bali (in Denpasar, July 13, 2017).

${ }^{34}$ Summary of interviews with Kristiawan/applicant to KPI-Central (in Jakarta, May 16, 2017) and Paulus Widiyanto/ former DPR Commission I member (in Jakarta, May 18, 2017). 
political elites and controller of the state have more influence on policy implementation. These multiple-principles are established through party cartelization. They strive to accumulate power, and they mutually struggle to accomplish their interest. For that, they employ their 'people' to occupy strategic government positions. The agents are nothing more than an extension of their authority, and they play a vital role in actualizing the mandate of the principles.

In relation to television broadcasting operation, the interest of the principle intertwined with the television capitalist group. Even some of the principles were also media owners and/or had good relations with media owners. Within the constellation of such relationship, the agent submits to the principles. The Minister of Communication and Information Technology's policy which was manifested in the ministerial regulation on the operation of digital terrestrial free-toair television broadcasting was an indication of such submission. In order to issue the regulation, the Minister dared to take a risk without considering Local-TV and public aspirations as well as existing laws and regulations. The regulation was clearly biased to the interest of political elites and the capitalist group. The result of the study provides a substantial contribution to the development of the principle-agent theory in examining policy implementation issues. This study also shows that capitalistic (economic) interest had not only affected the government's political actions. It was rather much more extensive than that, the economic interest among the principle(s) and also the agent(s) had led to the emergence of a number of political actions in the implementation of post-reform Indonesian broadcasting policy.

\section{References}

Ali, C. (2013). Where is here? An analysis of localism in media policy in three western democracies.
(Unpublished doctoral dissertation). The University of Pennsylvania.

Ambardi, K. (2008). The making of the Indonesian multiparty system: A cartelized party system and its origin (Unpublished doctoral dissertation). The Ohio State University. Armando, A., \& Henny, P. (2011). Televisi Jakarta di atas Indonesia: kisah kejanggalan sistem televisi berjaringan di Indonesia. Yogyakarta: Bentang.

Budiman, A. (1996). Teori negara: negara, kekuasaan, dan ideologi. Jakarta: Gramedia Pustaka Utama.

Crouch, H. A. (2010). Political reform in Indonesia after Soeharto. Singapore: ISEAS - Institute of Southeast Asian Studies.

Fischer, F., Miller, G.J., \& Sidney, M.S. (2015). Handbook analisis kebijakan publik: teori, politik dan metode (I. Baihaqie, Trans.). Bandung: Nusamedia.

Golding, P., \& Murdock, G. (1997). Culture, comunications and political economy. In Golding \& Murdock (Eds.), The political economy of the media. Cheltenham: Edward Elgar Publishing.

Goode, W. J. (1997). Rational choice theory. The American Sociologist, 28(2), 22-41.

Graham, P. (2007). Political economy of communication: a critique. Critical Perspectives on International Business, 3(3), 226-245.

Grindle, M. S., \& Thomas, J. W. (1989). Policy makers, policy choices, and policy outcomes: the political economy of reform in developing countries. Policy Sciences, 22(3-4), 213-248.

Herman, E. S., \& Chomsky, N. (2002). Manufacturing consent: The political economy of the mass media. NY: Pantheon Books.

Heychael, M. \& Wibowo, K.A. (2014). Melipat Indonesia dalam berita televisi: Kritik atas sentralisasi penyiaran. (Rep.). Jakarta: Remotivi, Fikom Unpad, Yayasan Tifa.

Judhariksawan. (2013). Kapita selekta hukum penyiaran. Makassar: Qalam Insani. 
Lim, M., (2011). @Crossroads: democratization $\mathcal{E}$ corporatization of media in Indonesia. Arizona: Participatory Media Lab at Arizona State University.

Jensen, M. C., \& Meckling, W. H. (1976). Theory of the firm: Managerial behavior, agency costs, and ownership structure. Journal of financial economics, 3(4), 305-360.

Matland, R. E. (1995). Synthesizing the implementation literature: the ambiguity conflict model of policy implementation. Journal of public administration research and theory, 5(2), 145-174.

Mosco, V. (2009). The Political Economy of Communication. Sage Publications

Nugroho, Y., Putri, DA., \& Laksmi, S. (2012). Mapping the landscape of the media industry in contemporary Indonesia. Report Series. Engaging media, empowering society: Assessing media policy and governance in Indonesia through the lens of citizens' rights. A research collaboration of Centre for Innovation Policy and Governance and HIVOS Regional Office Southeast Asia, funded by Ford Foundation. Jakarta: CIPG and HIVOS.

Pandjaitan, H. I. P., \& Siregar, A.S. (2003). Membangun sistem penyiaran yang demokratis di Indonesia. Jakarta: Warta Global Indonesia.
Pressman J, L., \& Wildavsky, A. B. (1973). Implementation: how great expectations in Washington are dashed in Oakland. Berkeley: University of California Press.

Rianto, P., Rahayu, Yusuf, I.A., Wahyono, B., Zuhri, S., Cahyono, M.F., Siregar, A.E. (2014). Kepemilikan dan intervensi siaran: perampasan hak publik, dominasi, dan bahaya media di tangan segelintir orang. Yogyakarta: PR2Media dan Yayasan Tifa.

Sabatier, P., \& Mazmanian, D. (1980). The implementation of public policy: A framework of analysis. Policy Studies Journal, 8(4), 538-560.

Schofield, J. (2004). A model of learned implementation. Public Administration, 82(2), 283-308.

Siregar, A.E. (2008, June 9). Sistem penyiaran yang demokratik. Retrieved from http://www. perspektifbaru.com/wawancara/638

Stavitsky, A.G. (1994). The changing conception of localism in U.S. public radio. Journal of Broadcasting E Electronic Media, 38(1), 19-33.

Underhill, G. R. (2000). State, market, and global political economy: genealogy of an (inter-?) discipline. International Affairs, 76(4), 805824.

Meter, D. S., \& Van Horn, C. E. (1975). The policy implementation process. Administration and Society, 6(4), 445-488. 